\title{
Suluova ve Merzifon Ovaları Topraklarının Yarayıșlı Demir, Bakır, Çinko ve Mangan Konsantrasyonlarının Mesafeye Bağlı Değișimi
}

\author{
Elif GÜNAL ${ }^{*}$
}

Halil ERDEM'

'Gaziosmanpașa Üniversitesi, Ziraat Fakültesi, Toprak Bilimi ve Bitki Besleme Bölümü, Tokat

*Sorumlu yazar e-posta (Corresponding author e-mail): elifgunal@gop.edu.tr

Geliș tarihi (Received) : 25.02.2015

Kabul tarihi (Accepted) : 02.10.2015

Öz

Bitki besin elementlerinin doğru amenajmanı, yüksek ürün elde etme ve çevresel kalitenin korunmasında oldukça önemlidir. Bu çalıșmanın amaçları; Suluova ve Merzifon Ovaları topraklarının DTPA'da ekstrakte edilebilir mikro element konsantrasyonlarını belirlemek, bu mikro elementlerin yarayıșlıı̆ına etki eden diğer toprak özellikleri ile ilișkisini anlamak ve mikro elementlerin mesafeye bağlı yapısını ortaya koymaktır. Merzifon ovasından 76 ve Suluova ovasından 143 adet toprak örneği alınmıș ve yarayıșlı çinko (Zn), demir $(\mathrm{Fe})$, bakır (Cu) ve mangan (Mn) konsantrasyonları ile toprak kil, silt ve kum içerikleri, $\mathrm{pH}$, elektriksel iletkenlik (EC), kalsiyum karbonat ve organik madde içerikleri belirlenmiștir. Tanımlayıcı istatistik sonuçları çalıșma alanının büyük bir kısmının Zn ve Fe açısından yetersiz, ancak Mn ve Cu bakımından toprakların yeterli olduğunu göstermiștir. Ortalama Zn ve Fe konsantrasyonları Merzifon ovasında sırasıyla $0.28 \mathrm{mg} \mathrm{kg}^{-1}$ ve $2.0 \mathrm{mg} \mathrm{kg}^{-1}$ ve Suluova ovasında ise $0.28 \mathrm{mg} \mathrm{kg}^{-1}$ ve $3.26 \mathrm{mg} \mathrm{kg}^{-1}$ dır. Toprakların Zn konsantrasyonu istatistiksel olarak $\mathrm{Mn}$ ile pozitif ve $\mathrm{pH}$ ile negatif önemli korelasyonlar $(\mathrm{P}<0.01)$ göstermiștir. Genelde $\mathrm{pH}^{\prime}$ nın yüksek olduğu yerlerde Zn yetersizliği görülürken, pH' nın 7.30-8.00 arasında olduğu bir kısım alanlarda Zn' nun bitkiler için yeterli düzeyde olduğu belirlenmiștir. Yarayıșlı Fe, Cu ve Mn ile pozitif korelasyonlara sahip iken, kum içeriği ile negatif korelasyon göstermiștir. Merzifon ovasında Fe, Suluova ovasında ise Fe, Zn ve Cu' ın mesafeye bağımlılığının yüksek olduğu belirlenmiștir. Diğer mikro elementlerin ise orta düzeyde mesafeye bağımlılık gösterdiği tespit edilmiștir. Jeoistatistiksel modellemede elde edilen range değerleri, çalıșma alanında ilgili özelliğin örneklenmesinde minimum mesafe olarak alınmalıdır.

Anahtar Kelimeler: Haritalama, jeoistatistik, mesafeye bağımlılık, mikroelement

\section{Spatial Variation of DTPA Extractable Iron, Copper, Zinc and Manganese Concentrations in Suluova and Merzifon Plain Soils}

\begin{abstract}
Appropriate plant nutrient management is important for achieving high crop yield and protecting environmental quality. The aims of this study are; i.) to determine the DTPA extractable micronutrient concentrations in Suluova and Merzifon Plains, ii.) to understand the relationship between micronutrients and related soil properties affecting the availability of micronutrients, and iii.) to figure out the spatial structure of micronutrients. Seventy-Six soil samples from Merzifon and 143 samples from Suluova Plain were collected to measure available zinc (Zn), iron (Fe), cupper (Cu) and manganese (Mn) concentrations along with soil clay, silt and sand contents, $\mathrm{pH}$, electrical conductivity (EC), calcium carbonate and organic matter contents. Descriptive results showed that Zn and Fe deficiencies were widespread throughout the study area while soils had sufficient amount of $\mathrm{Cu}$ and $\mathrm{Mn}$. Mean $\mathrm{Zn}$ and Fe concentrations in Merzifon Plain were respectively $0.28 \mathrm{mg} \mathrm{kg}^{-1}$ and $2.0 \mathrm{mg} \mathrm{kg}^{-1}$ and $0.28 \mathrm{mg} \mathrm{kg}^{-1}$ and $3.26 \mathrm{mg} \mathrm{kg}^{-1}$ for Suluova Plain, respectively. Soil $\mathrm{Zn}$ and Mn concentrations had positive and $\mathrm{pH}$ and $\mathrm{Zn}$ had negative
\end{abstract}


statistically important relations $(\mathrm{P}<0.01)$. In general, $\mathrm{Zn}$ concentrations were inadequate level at high $\mathrm{pH}$ locations whereas adequate $\mathrm{Zn}$ concentrations were obtained at locations where soil $\mathrm{pH}$ is between 7.20 to 8.00. Available Fe had positive correlations with $\mathrm{Cu}$ and $\mathrm{Mn}$ concentrations whereas statistically important negative correlations were obtained with sand content. Iron in Merzifon Plain and Fe, Zn and Cu in Suluova Plain had strong spatial dependency, while other micronutrients showed moderate spatial dependency. The range values obtained in geostatistical modeling should be taken into consideration as the minimum sampling distance for the future studies in the study area.

Key Words: Mapping, geostatistics, spatial dependency, micronutrient

\section{Giriș}

Toprakta bulunan mikro elementlerin bitkilerin gelișiminde oldukça önemli rolleri vardır ve genelde topraklarda oldukça düșük konsantrasyonlarda bulunurlar. Mikro elementlerin toprakta konsantrasyonları ana materyale, pedojenik ișlemlere (White ve Zasoski, 1999) ve bazı durumlarda topraktaki mikro element konsantrasyonlarının daha da azalmasına neden olan toprak amenajmanlarına bağlıdır (Pegoraro vd., 2006). Makro elementlere oranla çok daha düșük konsantrasyonlarda bulunan bu besin elementleri, bitkiler tarafından gereği kadar alınamadıklarında, bitkiler optimum gelișimlerini sağlayamazlar. Bu bitkiler ile beslenen hayvanlar ve insanlarda da, özellikle Zn ve Fe gibi mikro besin elementlerinin noksanlığından kaynaklanan bir kısım sağlık sorunları ortaya çıkabilmektedir (Alloway, 2008).

Mikro besin elementlerinin ana kaynağı toprak olduğundan, toprak özelliklerinin mikro elementlerin çözünürlüğünü ve yarayıș̦lı|ılarını nasıl etkilediklerini belirlemek son derece önemlidir. Mikro elementlerin bitki gelișimi için yarayıșllığı toprak tuzluluğu, asitliği, organik madde içeriği, tekstürü ve biyolojik aktiviteler gibi çeșitli faktörler tarafından etkilenir. Bu nedenle, mikro elementlerin topraktaki davranıșlarını tahmin edebilmek ve mikro elementlerin bitkilere yarayıșlılığını arttırmak için uygun yöntemleri tavsiye edebilmede bu parametrelerin belirlenmesi oldukça önemlidir (Foroughifar vd., 2013).

Toprakta bulunan mikro elementlerin mesafeye bağlı değișkenliklerinin sayısallaștııılması, ölçümlerin yapılmadığı ara noktalardaki mikro besin elementlerinin miktarlarının da tahmin edilmesini sağlamaktadır. Bu șekilde üretilen tahmin haritası, topraklarda mikro besin elementlerinin eksikliklerini anlama, lokasyonlarını tespit etme ve idaresi adına önemlidir (Heuvelink ve Webster, 2001). Belirli bir arazide mikro elementlerin bitkiye yarayıșlılıkları, benzer toprak ve çevre koșulları ile ilișkilidir. Toprakta bulunan mikro elementler arasındaki ilișkinin anlașılması, bu besin elementlerinin mesafeye bağlı değișkenliklerini etkileyen ve kontrol eden etmenlerin belirlenmesine de yardımcı olacaktır. Bu nedenle, mikro elementlerin mesafeye bağlı değișkenlikleri aralarındaki ilișkiyi de dikkate alacak șekilde incelenmelidir (Behera vd., 2011).

Bu çalıșmada Merzifon ve Suluova Ovalarının topraklarının mikro element içeriklerinin belirlenmesi ve mesafeye bağı dağılımlarının modellenerek haritalanması amaçlanmıștır. Ayrıca, mikro elementlerin arazideki dağılımlarına etki eden toprak özelliklerinin belirlenmesi, eksiklik veya fazlalıklarına etkileri gibi konular tartıșılmıștır.

\section{MATERYAL ve YÖNTEM}

Çalıșma alanı Amasya ilinin önemli tarımsal üretim merkezlerinden olan Suluova ve Merzifon ovalarını kapsamaktadır. Suluova Ovası, ilçe merkezi ve tüm yerleșim yerleri ile birlikte yaklașik 40.000 ha olup denizden yüksekliği ortalama 510 m'dir. Suluova Ovasında toprak örneklemelerinin yapıldığı çalıșma alanı ise, Tarım Reformu Genel Müdürlüğü' nün Arazi Islahı çalıșmalarını da yürüttüğü düz-düze yakın bir eğime sahip ve sulama imkânı olan toplam 6.019,30 ha'dır. Merzifon ovasının denizden yüksekliği ise ortalama 755 m'dir. Düz-düze yakın ve sulama olanağı bulunan toplam 2.644,7 ha araziden toprak örneklemeleri yapıımıștır (Șekil 1).

Merzifon'da iklim genellikle kıșları soğuk ve yağıșlı, yazları sıcak ve kuraktır. Merzifon'un uzun yıllar yağıș ortalaması 388,3 mm ve ortalama sıcaklık ise $11,7^{\circ} \mathrm{C}$ olarak ölçülmüștür. Merzifon Ovasına bitișik konumda olan Suluova Ovası, İç Anadolu Bölgesi karasal iklimi ile Karadeniz Bölgesi iklimi arasında kaldığından geçiș iklim özelliklerine sahip olup Suluova ilçesinin yıllık ortalama sıcaklığı 12,8 C'dir (Coban, 2003). 


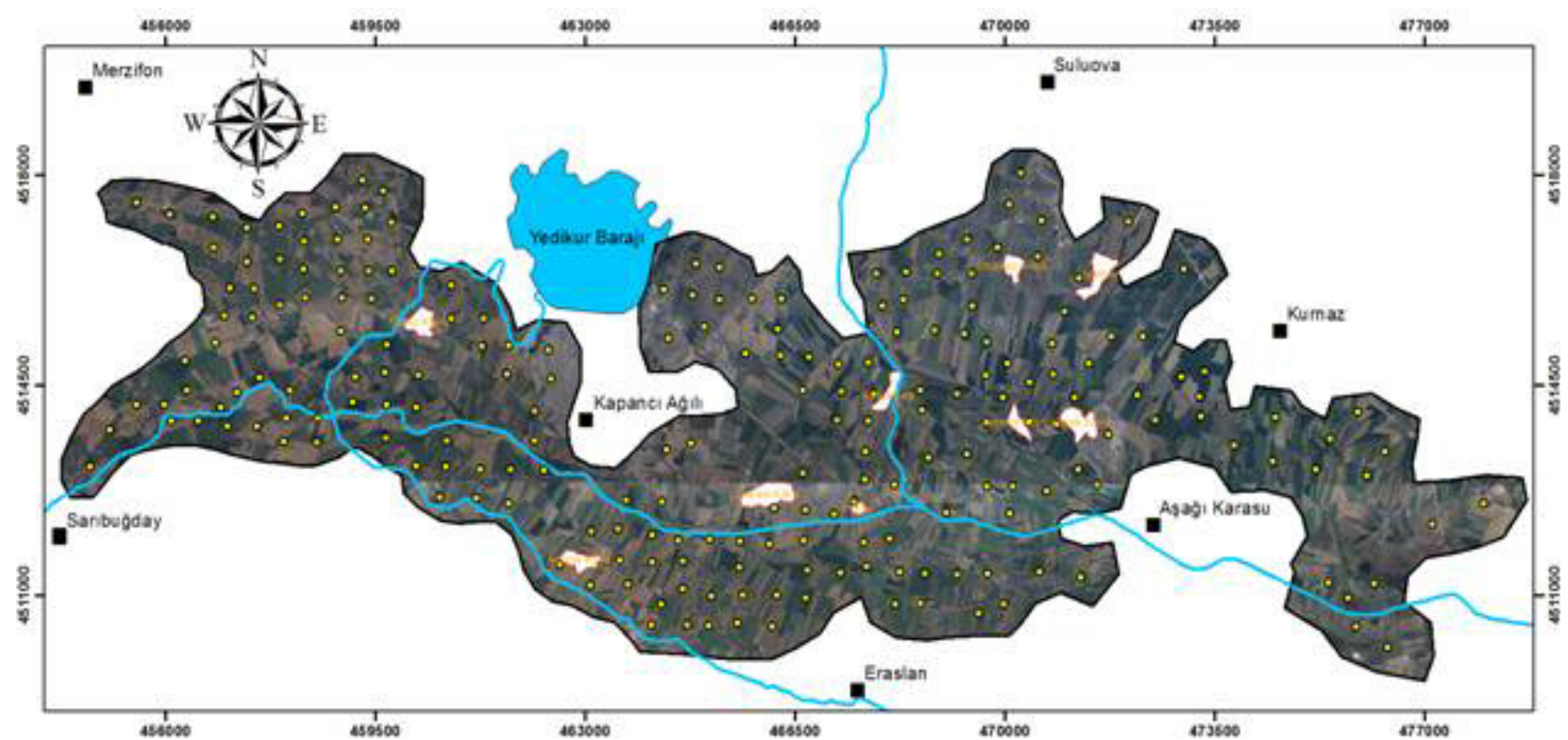

Șekil 1. Çalıșma alanı ve örnekleme noktalarını gösteren orto foto görüntüsü

Figure 1. Orto-photo image showing the study area and sampling locations

\section{Toprak Örneklemesi ve Analizleri}

Merzifon Ovasından 76 ve Suluova Ovasından 144 olmak üzere toplam 220 adet $0-30 \mathrm{~cm}$ derinliğinden toprak örnekleri alınmıștır. Araziler 500m X 500m genișliğinde gridlere ayrılmıș ve örneklemeler gridlerin köșe noktalarından yapıImıștır (Șekil 1).

Oda sıcaklığında kurutulan toprak örnekleri, tahta tokmaklar ile ufaltıldıktan sonra 2 mm'lik elekten geçirilmiș ve laboratuvar analizlerine hazır hale getirilmiștir. Örneklerin tekstür analizleri hidrometre yöntemi (Gee ve Bauder, 1986) ile, toprak reaksiyonu $(\mathrm{pH})$ ile elektriksel iletkenliği (EC) saturasyon çamurunda (Rhoades, 1982) belirlenmiștir. Organik madde içeriği Walkley-Black yöntemi ile (Nelson ve Sommers, 1982) ve örneklerin kireç içerikleri "Scheibler Kalsimetresi" yardımıyla (Allison ve Moodie, 1965) belirlenmiștir. Bitkiye elverișli olan mikro elementlerin Zn, Fe, Mn ve Cu tayininde DTPA yöntemi kullanılmıștır (Lindsay ve Norvell, 1978).

\section{İstatistiksel ve Jeoistatistiksel Analizler}

Çalıșma alanında belirlenen toprak özelliklerinin genel karakteristikleri, tanımlayıcı istatistik tabloları yapılarak sunulmuștur. Bu tablolarda verilerin merkezi eğilimlerini ortaya koyabilmek amacıyla en küçük ve en yüksek değerler ile verilerin aritmetik ortalamaları, yaygınlıklarını ortaya koyabilmek amaciyla standart sapmaları ve varyasyon katsayıları, verilerin dağıımının simetrikliğinin bir göstergesi olarak da yatıklık ve basıklık değerleri belirlenmiștir.

Çalıșma alanının mikro besin elementleri içeriklerinin haritalanmasında jeoistatistiksel teknikler kullanılmıștır. Jeoistatistik, örnekler arası mesafeye bağlı ilișkiyi tanımlamayı, modellemeyi ve haritalamayı amaçlayan bir metot olarak kullanılmaktadır (McBratney vd., 2000). Gözlem verilerinin deneysel variogram yapısının belirlenmesi ve bu yapıya teorik bir modelin uydurulması jeoistatistiksel çalıșmaların temelini olușturmaktadır (Vieira vd., 1981). Her bir özelliğin mesafeye bağımlılığının belirlenmesi için yapılan modelleme ve uygun enterpolasyon yönteminin belirlenmesinin ardından, çalıșma alanında örnekleme yapılmayan noktalar için tahminlerin yapılmasının ardından haritalama șeklinde iki așamalı olarak gerçekleștirilmiștir.

Haritalanan özelliklere ait semivaryogramlar GS+ 7.0 (Gamma Design Software, 2004) paket programı kullanılarak modellenmiș, krigleme ișlem ve sonrasında üretilen haritalar ise ArcGIS 9.2 (Esri, 2006) paket programı kullanılarak yapılmıștır. Olușturulan nihai haritalar 100x100m'lik raster formatına dönüștürülüp, arazinin sınırları boyunca bu raster katmanı kesilip lejantlar eklenerek haritalar elde edilmiștir. 
Uygun enterpolasyon modeline ait variogramların range, sill ve nugget değerleri belirlenmiș, her bir özelliğin mesafeye bağımlılığı hesaplanmıștır. Mesafeye bağımlılık değeri, nugget semivaryansın toplam semivaryansa oranının $(\mathrm{Co} / \mathrm{Co}+\mathrm{C})$ yüzde olarak ifadesidir. Șayet mesafeye bağımlılık değeri $\leq \% 25$ ise değișken kuvvetli mesafeye bağımlı, \%25-75 arasında ise orta derecede mesafeye bağımlı olarak sınıflandırımakta ve bu oran $\% 75^{\prime}$ den fazla ise değișken zayıf mesafeye bağımlı olarak sınıflandırılmaktadır (Camberdella vd., 1994).

\section{BULGULAR VE TARTIȘMA}

\section{Merzifon Ovası Toprak Özellikleri}

Merzifon toprakları çoğunlukla killi tekstüre sahip olup, ortalama kil içeriği \%51,8'tir. Bununla beraber ovada kum içeriği \%64,2 gibi yüksek olan Iokasyonlarda bulunmaktadır. Özellikle çalıșma alanı içerisinden geçen derelerin yakınlarında yer alan araziler, derelerin sedimentleri depolama desenine uygun bir șekilde daha kaba tekstürlü iken, derelerden uzaklaștıkça kil içeriğinin arttığı görülmektedir. Çalıșma alanı topraklarının saturasyon çamurunda belirlenen pH'sı bölgenin iklimi ve ana materyalinin özelliklerinin de etkisi ile genelde hafif alkali ve kuvvetli alkali olup, 8, 15-9,52 arasında değișirken, ortalama 8,51 olarak bulunmuștur. Merzifon ovasında ortalama EC değerleri tuzluluk probleminin olmadığını göstermekle beraber, sınırlı sayıda örnekleme noktasında EC değeri bitkisel üretimde sorun yaratacak seviyede yüksek bulunmuștur (Çizelge 1).
Çalıșma alanında Ülgen ve Yurtseven (1974)' e göre ortalama organik madde içeriği $(\% 1,58)$ az olarak bulunmuștur. Bununla beraber organik madde içeriğinin \%0,20 gibi çok az olduğu ve \%3,59 gibi iyi olduğu örnekleme noktaları da yer almaktadır. Bu değișkenliğin temel nedeni 2.644,7 ha olan çalıșma alanında yapılan farklı tarımsal uygulamalardır. Allison ve Moodie (1965)' ye göre toprakların kireç içerikleri gruplandırıldığında ova topraklarının orta kireçli (\%5-15) ve yüksek kireçli (\%15-25) olduğu görülmüștür (Çizelge 1).

Merzifon topraklarının Zn konsantrasyonları 0,11

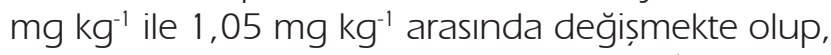
ortalama Zn konsantrasyonu $\left(0,28 \mathrm{mg} \mathrm{kg}^{-1}\right)$, Lindsay ve Norvell (1978) tarafindan topraklarda noksanlık sınır değeri olarak belirtilen $0.5 \mathrm{mg} \mathrm{kg}^{-12}$ ın altındadır. Merzifon Ovasında örneklenen 76 noktadan 69 tanesinde Zn konsantrasyonu belirtilen sınır değerin altında olduğundan, ovanın önemli bir kısmında yetiștirilen kültür bitkilerinin Zn içeren gübre uygulanmadığı takdirde Zn noksanlığından dolayı verim düșüșü riski bulunmaktadır.

Toprakta havalanmanın durumuna bağlı olarak $\mathrm{Fe}^{+3}$ ve $\mathrm{Fe}^{+2}$ formalarında bulunan Fe'in bitkilere yarayıșlılı̆ı, topraktaki formu ve kimyasal özellikleri, toprak pH'sı, toprak kolloidleri ile etkileșimi, mikrobiyal aktivite, organik madde içeriği, havalanma, sıkıșma, sıcaklık, nem ve diğer besin elementlerinin konsantrasyonları tarafından etkilenmektedir (Hodges, 2010). Merzifon Ovasında toprakların Fe konsantrasyonları, 0,60-4,67 mg kg-1 arasında değișmiș ve ortalama $2,00 \mathrm{mg} \mathrm{kg}^{-1}$ olarak bulunmuștur (Çizelge 1).

Çizelge 1. Merzifon Ovası topraklarının bir kısım fiziksel ve kimyasal özellikleri ile mikro element içeriklerinin tanımsal istatistikleri

Table 1. Some of physical, chemical characteristics and micro nutrient contents of soils in Merzifon Plain

\begin{tabular}{lcrrrrrrr}
\hline $\mathrm{N}=76$ & Birim & $\begin{array}{c}\text { En } \\
\text { Küçük }\end{array}$ & $\begin{array}{c}\text { En } \\
\text { Büyük }\end{array}$ & Ortalama & $\begin{array}{c}\text { Std. } \\
\text { Sapma }\end{array}$ & \multicolumn{1}{c}{ CV* } & Yatıklık & Basıklık \\
\hline Kil & $\%$ & 26,3 & 67,0 & 51,8 & 9,605 & 18,56 & $-0,82$ & 0,14 \\
Kum & $\%$ & 12,2 & 64,2 & 27,3 & 9,975 & 36,55 & 1,58 & 3,28 \\
Silt & $\%$ & 7,1 & 37,5 & 21,0 & 6,273 & 29,93 & 0,62 & 0,58 \\
Zn & mg kg-1 $^{-1}$ & 0,11 & 1,05 & 0,28 & 0,177 & 62,28 & 2,09 & 5,05 \\
Fe & mg kg $^{-1}$ & 0,60 & 4,57 & 2,00 & 0,765 & 38,32 & 1,43 & 2,42 \\
Cu & mg kg $^{-1}$ & 0,48 & 1,29 & 0,80 & 0,216 & 27,14 & 0,53 & $-0,72$ \\
$\mathrm{Mn}$ & $\mathrm{mg} \mathrm{kg}^{-1}$ & 0,79 & 7,74 & 3,81 & 1,579 & 41,44 & 0,66 & $-0,15$ \\
$\mathrm{PH}$ & & 8,15 & 9,52 & 8,51 & 0,231 & 2,72 & 1,75 & 5,42 \\
$\mathrm{EC}^{* *}$ & $\mathrm{dS} \mathrm{m}$ & 0,21 & 3,70 & 0,54 & 0,393 & 72,89 & 7,08 & 57,15 \\
$\mathrm{OM}^{* * *}$ & $\%$ & 0,20 & 3,59 & 1,58 & 0,655 & 41,53 & 0,40 & 0,56 \\
$\mathrm{CaCO}_{3}$ & $\%$ & 6,22 & 24,12 & 14,56 & 3,396 & 23,33 & 0,15 & 1,12 \\
\hline
\end{tabular}

* CV: Varyasyon Katsayısı (\%), ** EC: Elektriksel Iletkenlik, *** OM: Organik Madde 
Lindsay ve Norvell (1969), toprakları, Fe içeriği ile ilgili olarak; Fe konsantrasyonu $<2,5 \mathrm{mg} \mathrm{kg}^{-1}$ olduğunda az, 2,5-4,5 $\mathrm{mg} \mathrm{kg}^{-1}$ arasında olduğunda orta ve $>4,5 \mathrm{mg} \mathrm{kg}^{-1}$ olduğunda ise fazla șeklinde gruplandırmıșlardır. Buna göre, Merzifon ovasında DTPA'da ekstrakte edilebilen ortalama Fe içeriğinin bitki gelișimi için yeterli olmadığı anlașıımaktadır. Örnekleme yapılan 76 noktadan 46 tanesinde Fe içeriğinin $2 \mathrm{mg} \mathrm{kg}^{-1}$ dan daha düșük olduğu belirlenmiștir (Çizelge 1).

Tarım topraklarının toplam Cu içeriğinin 50 mg $\mathrm{kg}^{-1}$ 'a kadar yüksek olabileceği belirtilmektedir. Topraklarda Cu çok çeșitli formlarda bulunmakla beraber, bitki besleme açısından en yararlı olanları çözünmüș ve değișebilir formda olan $\mathrm{Cu}^{\prime}$ dır. Merzifon topraklarının Cu içeriği 0,48-1,29 mg kg-1 arasında değișmekte olup, ortalama Cu içeriği 0,80 mg kg-1'dır (Çizelge 1). Follet (1969), DTPA çözeltisi ile ekstrakte edilebilir $\mathrm{Cu}$ içeriğine göre toprakları yetersiz $\left(<0,2 \mathrm{mg} \mathrm{kg}^{-1}\right)$ ve yeterli $\left(>0,2 \mathrm{mg} \mathrm{kg}^{-1}\right)$ olacak șekilde iki gruba ayırmıștır. Bu sınıflamaya göre Merzifon Ovası toprakları, DTPA ile ekstrakte edilebilir $\mathrm{Cu}$ konsantrasyonu açısından yeterli görülmektedir. Bakırın yarayıșlıı̆ı $\mathrm{pH}$ 7,0 ve üzerinde azalmakta ve yarayıșlığın en yüksek olduğu $\mathrm{pH}$ değerinin ise 5,0 olduğu belirtilmektedir. Çalıșma alanı topraklarının ortalama $\mathrm{pH}$ değerinin 8,51 olması, çalıșma alanında yarayıșlı $\mathrm{Cu}$ içeriğinin çok yüksek olmamasının nedenlerinden biri olarak düșünülebilir. Tarım topraklarında toplam $50 \mathrm{mg} \mathrm{kg}^{-1}$ a kadar toplam $\mathrm{Cu}$ konsantrasyonu bulunabilirken, Merzifon Ovasında ortalama Cu içeriği 0,80 $\mathrm{mg} \mathrm{kg}^{-1}$ olarak bulunmuștur. Bu çalıșmada her ne kadar toplam $\mathrm{Cu}$ içeriği belirlenmemiș olsa da, genel itibari ile toplam Cu konsantrasyonu yüksek olan topraklarda yarayıșlı Cu konsantrasyonunun toplam Cu'a göre düșük olması, Reyhanitabar ve Karimian (2008), belirttiği gibi yüksek kil içeriği ve kalsiyum karbonatın yüzey alanı ile ilișkilendirilebilir. Ortalama kireç içeriği \%14,56 olan Merzifon Ovası topraklarının ortalama \%51,75 gibi yüksek kil içeriğine sahip olması $\mathrm{Cu}^{\prime}$ ın çözünebilirliğini zorlaștıran önemli faktörlerdir. Benzer șekilde Dudley vd., (1991), kireçli topraklarda Cu' ın spesifik adsorpsiyon reaksiyonları ile tutulduğunu ve karbonatların bulunduğu koșullarda Cu'ın etkin bir șekilde hareketsiz hale geçirilebileceğini belirtmișlerdir.

Merzifon Ovası topraklarının DTPA'da ekstrakte edilebilir Mn içeriği $0,79 \mathrm{mg} \mathrm{kg}^{-1}$ ile $7,4 \mathrm{mg} \mathrm{kg}^{-1}$ arasında değișmiș ve ortalama $3,81 \mathrm{~kg}^{-1}$ olarak bulunmuștur. Dünya Gıda ve Tarım Organizasyonu (FAO, 1990)' nun belirlediği kriterlere göre, Mn içeriği $14 \mathrm{mg} \mathrm{kg}^{-1}$ 'dan düșük olan konsantrasyonlar toprakta yetersiz olarak tanımlanmaktadır.

\section{Suluova Ovası Toprak Özellikleri}

Suluova Ovası topraklarının kil içeriği, \%23,674,0 arasında değișmekte olup ortalama \%52, 1 'dir. Ortalama kil içeriğinden de anlașılacağı gibi ovanın genelinde toprakların kil içeriği yüksektir. Bununla beraber en yüksek kum içeriğine bakıldığında ovada \%50 civarında kum içeren lokasyonların da olduğu anlașılmaktadır. Toprak reaksiyonu Suluova Ovasında 8,06-9,47 arasında değișirken ovanın

Çizelge 2. Suluova Ovası topraklarının bir kısım fiziksel ve kimyasal özellikleri ile mikro element içeriklerinin tanımsal istatistikleri

Table 2. Some of physical, chemical characteristics and micro nutrient contents of soils in Suluova Plain

\begin{tabular}{lccclclll}
\hline $\mathrm{N}=143$ & Birim & $\begin{array}{c}\text { En } \\
\text { Küçük }\end{array}$ & $\begin{array}{c}\text { En } \\
\text { Büyük }\end{array}$ & Ortalama & $\begin{array}{c}\text { Std. } \\
\text { Sapma }\end{array}$ & CV* & Yatıklık & Basıklık \\
\hline Kil & $\%$ & 23,6 & 74,0 & 52,1 & 10,587 & 20,32 & $0-, 63$ & $-0,17$ \\
Kum & $\%$ & 8,1 & 50,1 & 24,4 & 7,510 & 30,75 & 0,58 & 0,38 \\
Silt & $\%$ & 10,0 & 42,5 & 23,5 & 6,898 & 29,39 & 0,48 & $-0,10$ \\
Zn & $\mathrm{mg} \mathrm{kg}^{-1}$ & 0,05 & 1,21 & 0,28 & 0,179 & 64,89 & 2,32 & 7,42 \\
$\mathrm{Fe}$ & $\mathrm{mg} \mathrm{kg}^{-1}$ & 1,02 & 6,93 & 3,04 & 0,967 & 31,80 & 0,92 & 1,51 \\
$\mathrm{Cu}$ & $\mathrm{mg} \mathrm{kg}^{-1}$ & 0,28 & 1,59 & 1,02 & 0,217 & 21,21 & $-0,16$ & 0,48 \\
$\mathrm{Mn}$ & $\mathrm{mg} \mathrm{kg}^{-1}$ & 0,99 & 8,32 & 3,86 & 1,414 & 36,61 & 0,88 & 0,50 \\
$\mathrm{PH}$ & & 8,06 & 9,47 & 8,50 & 0,269 & 3,16 & 1,21 & 1,69 \\
$\mathrm{EC}$ & $\mathrm{dS} \mathrm{m}{ }^{-1}$ & 0,22 & 4,67 & 0,63 & 0,669 & 106,23 & 4,21 & 19,11 \\
$\mathrm{OM}^{* *}$ & $\%$ & 0,42 & 7,27 & 1,71 & 0,797 & 46,73 & 3,20 & 17,87 \\
$\mathrm{CaCO}_{3}^{* * *}$ & $\%$ & 9,25 & 28,82 & 17,12 & 3,489 & 20,38 & 0,74 & 0,86 \\
\hline
\end{tabular}

* CV: Varyasyon Katsayısı (\%),** EC: Elektriksel İletkenlik, *** OM: Organik Madde 
ortalama pH değerinin kuvvetli alkali kabul edilen 8,50'de olduğu görülmektedir (Çizelge 2).

Ortalama EC değerlerine bakıldığında $(0,63$ dS $\mathrm{m}^{-1}$ ) Suluova Ovası topraklarının tuz probleminin olmadığı söylenebilir, ancak en yüksek EC değerleri arasında $4,67 \mathrm{dS} \mathrm{m}^{-1}$ değerinin olması, ovada yer yer tuz problemi olan alanların olduğuna ișaret etmektedir. Ovanın organik madde içeriği, yoğun toprak ișlemeli tarımın yapıldığı sahalarda \%0,42 ve mera olarak kullanılan arazilerde \%7,27 iken, ovanın ortalama organik madde içeriği \%1,71'dir. Ova toprakları ortalama \%17,12 kireç içermekte ve bu değer örnekleme yerine göre değișmektedir (Cizelge 2).

Benzer iklim, ana materyal ve çiftçi alıșkanlıkları olduğundan dolayı $\mathrm{Fe}, \mathrm{Zn}, \mathrm{Cu}$ ve $\mathrm{Mn}$ içerikleri ile ilgili olarak Suluova Ovasında da Merzifon Ovasına oldukça benzer bir durum söz konusudur. Çinko konsantrasyonu 0,05-1,21 mg $\mathrm{kg}^{-1}$ arasında değișirken ortalama $0,28 \mathrm{mg} \mathrm{kg}^{-1}$ olarak bulunmuștur. Ortalama Zn konsantrasyonu ovada yer alan toprakların ciddi anlamda Zn açısından yetersiz olduğuna ișaret etmektedir. Örnekleme yapılan 143 noktanın 129 tanesinde Zn konsantrasyonunun $0,5 \mathrm{mg} \mathrm{kg}{ }^{-1}$ 'dan düșük olması da bunu kanıtlar niteliktedir. Çalıșma alanında yapılan tarımsal üretimde özellikle Zn gibi mikro elementlerin kullanımının yetersiz olması ve uzun süredir yoğun tarımsal faaliyetlerin yapılıyor olması toprakların Zn konsantrasyonlarının düșük olmasına yol açmıștır.
Çalıșma alanı topraklarının Fe içeriği ise, 1,026,93 $\mathrm{mg} \mathrm{kg}^{-1}$ arasında değișmiș ve ortama 3,04 $\mathrm{mg} \mathrm{kg}^{-1}$ olarak bulunmuștur. Bu değer, Linsay ve Norvell (1979)' ın belirtmiș olduğu yeterlilik sınır değerlerinin $\left(>2,5 \mathrm{mg} \mathrm{kg}^{-1}\right)$ üzerindedir. Suluova Ovasında ortalama Cu $\left(1,02 \mathrm{mg} \mathrm{kg}^{-1}\right)$ ve ortalama $\mathrm{Mn}\left(3,86 \mathrm{mg} \mathrm{kg}^{-1}\right)$ konsantrasyonları, $\mathrm{Cu}$ ve $\mathrm{Mn}$ açısından da ovada sorunun olmadığını göstermektedir.

\section{Merzifon ve Suluova Ovalarının Toprak Özelliklerinin Korelasyonları}

Bugüne kadar yapılan çalıșmaların bir çoğunda (Sharma vd., 2004; Wu vd., 2010) bir kısım temel toprak özellikleri ile mikro element içerikleri arasındaki ilișki çalıșılmıș ve çoğunlukla mikro elementlerin yarayıșlığını etkileyen en önemli toprak bileșeninin toprak pH'sı ve organik madde içeriği olduğu ifade edilmiștir. Bu ilișkiyi belirlemek için yapılan korelasyon analizinde, çalıșma alanı topraklarının organik madde içerikleri ile konsantrasyonları tayin edilen mikro elementlerden hiç birinin negatif veya pozitif istatistiksel olarak önemli bir ilișkisi olduğu tespit edilememiștir (Cizelge 3). Bununla beraber, toprak $\mathrm{pH}$ 'sı ile $\mathrm{Mn}$ ve $\mathrm{Zn}$ arasında ise istatistiksel olarak önemli $(P<0,01)$ negatif korelasyonlar olduğu görülmüștür.

Sharma vd., (1999 ve 2004), yaptıkları iki ayrı çalıșmada mikro elementlerin yarayıșlılıkları ile toprakların kalsiyum karbonat içeriği, katyon değișim kapasitesi, kil ve kum içerikleri arasında önemli ilișkiler tespit etmișlerdir. Çizelge 3' de

Çizelge 3. Suluova ve Merzifon Ovaları toprak özelliklerinin korelasyonu.

Table 3. Correlations for soil characteristics of Suluova and Merzifon Plains

\begin{tabular}{|c|c|c|c|c|c|c|c|c|c|c|c|}
\hline$N=218$ & $\mathrm{Cu}$ & $\mathrm{Mn}$ & $\mathrm{Fe}$ & $\mathrm{Zn}$ & Kil & Kum & Silt & $\mathrm{pH}$ & EC & $\mathrm{OM}$ & $\mathrm{CaCO}_{3}$ \\
\hline $\mathrm{Cu}$ & 1 & & & & & & & & & & \\
\hline $\mathrm{Mn}$ & 0,105 & 1 & & & & & & & & & \\
\hline $\mathrm{Fe}$ & $0,606^{* *}$ & $0,340^{* *}$ & 1 & & & & & & & & \\
\hline Zn & $-0,050$ & $0,355^{* *}$ & $-0,032$ & 1 & & & & & & & \\
\hline Kil & $0,309^{* *}$ & $-0,236^{*}$ & 0,123 & $-0,180$ & 1 & & & & & & \\
\hline Kum & $-0,234^{*}$ & 0,107 & $-0,226^{*}$ & 0,064 & $-0,795^{* *}$ & 1 & & & & & \\
\hline Silt & $-0,101$ & $0,192^{\circ}$ & 0,172 & 0,174 & $-0,266^{*}$ & $-0,372^{* *}$ & 1 & & & & \\
\hline $\mathrm{pH}$ & 0,107 & $-0,321^{* *}$ & 0,001 & $-0,438^{* *}$ & 0,062 & 0,120 & $-0,286^{* *}$ & 1 & & & \\
\hline EC & 0,162 & $-0,003$ & 0,059 & $-0,027$ & 0,069 & 0,080 & $-0,233^{*}$ & $-0,023$ & 1 & & \\
\hline OM & $-0,049$ & 0,101 & $-0,088$ & 0,155 & 0,123 & $-0,195^{*}$ & 0,121 & $-0,151$ & 0,017 & 1 & \\
\hline $\mathrm{CaCO}_{3}$ & $-0,199^{*}$ & $-0,123$ & 0,056 & 0,157 & $0,410^{* *}$ & $-0,490^{* *}$ & 0,151 & $-0,026$ & $-0,088$ & 0,016 & 1 \\
\hline
\end{tabular}

* P<0.01 düzeyinde istatistiksel olarak önemlidir

** P<0.05 düzeyinde istatistiksel olarak önemlidir 
görüldüğü gibi, çalıșma alanında kalsiyum karbonat içeriği ile ilișkili tek mikro elementin $\mathrm{Cu}^{\prime}$ dır. Tekstür bileșenlerinden kil ile $\mathrm{Cu}$ ve $\mathrm{Mn}$ arasında (pozitif), kum ile $\mathrm{Cu}$ ve Fe arasında (negatif) ve silt ile $\mathrm{Mn}$ arasında (pozitif) istatistiksel olarak önemli \%1 ve \%5 düzeyinde ilișkiler olduğu belirlenmiștir. Kum ile mikro elementler arasındaki istatistiksel olarak önemli negatif ilișkiyi Sharma vd., (2009), kum fraksiyonu içerisinde yer alan yüksek kuvars mineralinin varlığı ile açıklamıșlardır. Elektriksel yapısı nötr olan kuvars mineralinin yoğun olduğu topraklarda, mikro elementlerin tutunması mümkün olamadığından yarayıșlı konsantrasyonları da düșük olmaktadır.

Ekstrakte edilebilir Zn içeriği ile yarayıșı Mn içeriği arasında istatistiksel olarak önemli pozitif $(P<0,01)$ bir ilișki tespit edilirken, $\mathrm{Zn}$ ile $\mathrm{pH}$ arasında önemli negatif $(P<0,01)$ bir ilișki belirlenmiștir (Çizelge 3$)$. Bu durumda çalıșma alanında yer alan topraklarda, yarayıșlı Zn içeriğinin yüksek olduğu yerlerde Mn içeriğinin de yüksek olacağı beklenmelidir. Kaliforniya topraklarında yaptıkları bir çalıșmada Bradford vd., (1996), nikel ve krom, magnezyum ve nikel, kobalt ve bakır ile krom ve magnezyum arasında görülen yüksek korelasyonunun nedenini toprakların ana materyali olan serpantin kayasına dayandırmıșlardır.

Serpantin içerisinde bulunan bu elementlerin konsantrasyonları, ayrıșma ürünü olan toprakta benzerlik göstermiștir. Çalıșma alanı toprakıarını olușturan ana materyallerin nispeten homojen olması Zn ile Mn arasındaki yüksek korelasyona neden olduğu düșünülmektedir. Benzer șekilde, İran'da toprakların bir kısım mikro element dağıımları üzerine jeo-pedolojik koșulların etkisini araștıran Nael vd., (2009), topraklardaki mikro element konsantrasyonlarının esas olarak ana materyal çeșidi ile ilișkili olduğunu rapor etmișlerdir.

Bunun tam aksi bir ilișkinin belirlendiği yarayıșlı $\mathrm{Zn}$ ile $\mathrm{pH}$ arasındaki önemli negatif ilișki ise, $\mathrm{pH}$ değerinin artıș veya azalıșına bağlı olarak, topraktaki Zn konsantrasyonun yarayıșlılığının arttığı veya azaldığı söylenebilir. Çalıșılan topraklarda görülen negatif ilișki, pH'nın yükselmesi ile birlikte, yarayıșlı Zn içeriğinin azaldığını ve aksi durumda ise $\mathrm{Zn}$ konsantrasyonunun arttığını göstermiștir. Bursa ili Kireçsiz Kahverengi büyük toprak grubu topraklarının bazı özellikleri ve besin maddesi içeriklerini belirleyen Tümsavaș ve Çelik (2005), toprakların pH'larının hafif asidik ile nötr ve hafif alkalin arasında değiștiğini ifade etmiș ve toprakların değișebilir Fe, Mn, Cu ve Zn içerikleri yönünden yeterli olduklarını belirlemișlerdir. Bununla beraber, pH'sı çoğunlukla 8,0'ın üzerinde olan kireç içeriği yüksek Niğde'de Emen Ovası topraklarında çalıșan Erdem vd., (2012) ise, çalıșılan toprakların çoğunluğunda özellikle ekstrate edilebilir Zn içeriğinin düșük olduğunu rapor etmișlerdir. Erdem vd., (2012), çalıșma yaptıkları alanın $\mathrm{pH}$ değerlerine benzer olan çalıșma alanı topraklarının Zn içeriğinin düșük olmasında $\mathrm{pH}$ değerlerinin yüksek olmasının da önemli bir etken olduğu düșünmektedirler. Bir kısım çalıșmalarda (Wenming vd., 2001), kireçli topraklarda $Z n$ ' nun adsorpsiyonu ve dolayısı ile yarayıșlılığı üzerine en etkili toprak bileșeninin $\mathrm{CaCO}_{3}$ olduğu belirtilmesine rağmen, çalıșma alanı topraklarında da $\mathrm{Zn}$ ile $\mathrm{CaCO}_{3}$ arasında önemli bir ilișkinin varlığı tespit edilememiștir. Benzer șekilde, Güney İran' da kireçli toprakların mikro element içerikleri ile toprak özellikleri arasındaki ilișkiyi araștıran Nafaji-Ghiri vd., (2013), Zn konsantrasyonu ile $\mathrm{CaCO}_{3}$ arasında önemli bir ilișki bulunamadığını belirtmișlerdir.

Bitkiler tarafından $\mathrm{Cu}^{\prime}$ ın alımının azot, fosfor, $\mathrm{Zn}, \mathrm{Mn}$ ve molibden gibi besin elementleri tarafından da olumsuz etkilendiği bildirilmiștir (Hodges, 2010). Çalıșmamızda ise, $\mathrm{Cu}$ ile $\mathrm{Fe}$ arasında önemli bir pozitif ilișki $(P<0.01)$ tespit edilmiș, bununla beraber Cu ile Mn ve Zn arasında istatistiksel olarak önemli herhangi bir ilișkiye rastlanamamıștır. Bakır ile tekstür bileșenlerinden kil arasında önemli pozitif bir ilișki var iken, kum içeriği arasında negatif bir ilișkinin varlığı tespit edilmiștir (Çizelge 3). İran'da oldukça yüksek kireç içeren toprakların yarayıșlı Cu tamponlama kapasitesi üzerine çalıșmalar yapan çalıșan Ghasemi-Fasaei vd., (2006), yarayıșlı Cu konsantrasyonunun toprağın kireç içeriği, katyon değișim kapasitesi ve kil içeriği ile ilișkili olduğunu belirlemișlerdir. Bu çalıșmada da DTPA ile ekstrakte edilebilen $\mathrm{Cu}$ konsantrasyonu üzerine etkili olan parametreler Ghasemi-Fasaei vd., (2006) 'nin bildirdiği özellikler ile uyumludur. Çalıșmada $\mathrm{Cu}$ konsantrasyonunun, katyon değișim kapasitesi üzerinde oldukça etkili olan kil içeriği ile pozitif ve kum içeriği ile negatif korelasyona sahip olması, çalıșma alanı topraklarında yarayıșlı Cu konsantrasyonuna etki eden en önemli unsurların tekstür bileșenleri olduğunu göstermektedir. Bununla birlikte Najafi-Ghiri vd., (2013), yarayıșlı Cu konsantrasyonuna etki eden parametreler içerisine katyon değișim kapasitesi ve kireç içeriğine ilaveten 
organik maddeyi de dahil etmișlerdir. Wu vd., (2010), Cu ile $\mathrm{pH}$ ve organik madde arasında önemli bir ilișki bulunduğunu bildirmișlerdir. Çalıșmamızda $\mathrm{Cu}$ konsantrasyonu ile bu araștırıcıların belirttiği parametreler arasında önemli bir ilișki belirlenmemiștir.

Hong vd., (2010), pH değerinin artıș ile birlikte özellikle kireç içeriği yüksek olan topraklarda Mn' nın çözünmesi zor bileșikler olușturmasından dolayı bitkilere yarayıșııı̆ının azalacağı ve bitkilerde noksanlık görülebileceğini belirmișlerdir. Araștırma alanında yer alan her iki ovada da yaklașı $3.80 \mathrm{mg}$ $\mathrm{kg}^{-1}$ 'In üzerinde olan ortalama Mn konsantrasyonu, bitkiler açısından bir noksanlığa ișaret etmemekle birlikte, $\mathrm{pH}$ değerleri ile $\mathrm{Mn}$ konsantrasyonu arasında istatistiksel olarak önemli $(P<0,01)$ bulunan negatif korelasyon, $\mathrm{pH}$ artıșı ile birlikte $\mathrm{Mn}$ konsantrasyonunun azaldığını göstermektedir (Çizelge 3). Bu sonucu destekler nitelikte, Havlin vd., (1999), toprakta $\mathrm{pH}^{\prime}$ nın her bir birim artıșı ile Mn+2'nin çözünürlüğünün 100 kat azalacağını rapor etmișlerdir.

\section{Merzifon Ovası Topraklarının Mesafeye Bağlı Değișimleri}

Merzifon topraklarında mikro elementlerin tamamı üssel ve Suluova Ovası topraklarında ise üssel ve küresel modeller kullanılarak modellenmiștir. Modelleme ile elde edilen range değeri, gözlemlerin arazide benzerliğinin bittiği mesafeyi ifade etmekte kullanılır. Mangan konsantrasyonlarına ait semivariogramın uzunrange yapısı, muhtemelen kayaç gibi kalıtsal bir özellik tarafından kontrol edildiğine ișaret etmektedir. Buna karșilık en düșük range değerine sahip olan Fe konsantrasyonunun ise lokal olarak insan aktiviteleri tarafından etkilendiğini göstermektedir. Demir konsantrasyonlarına ait semivariogramın range değeri 1191 m'dir. Bundan sonraki en kısa range değerine sahip element $\mathrm{Cu}^{\prime}$ dır. Merzifon Ovası topraklarının mikro element içeriklerinden $\mathrm{Fe}$ yüksek düzeyde mesafeye $(\% 5,93)$ bağımlılık gösterirken, Cu $(\% 70,24), \mathrm{Mn}$ $(49,96)$ ve $Z n^{\prime}$ nun $(\% 31,29)$ mesafeye bağımlıı̆ıının orta düzeyde olduğu belirlenmiștir (Çizelge 4).

Çizelge 4. Merzifon Ovası topraklarına ait semivariyogram model parametreleri

Table 4. Semivariogram model parameters of Merzifon Plain soils

\begin{tabular}{llllllllll}
\hline & Model & $\begin{array}{l}\text { Aktif Lag } \\
\text { Mesafesi }\end{array}$ & $\begin{array}{l}\text { Uniform } \\
\text { Aralık }\end{array}$ & $\begin{array}{l}\text { Nugget } \\
\text { Varyansı } \\
\text { Co }\end{array}$ & $\begin{array}{l}\text { Sill } \\
\text { Co+C }\end{array}$ & $\begin{array}{l}\text { Uzaysal } \\
\text { Bağımlılık } \\
\%\end{array}$ & $\begin{array}{l}\text { Range } \\
\text { (A) } \mathrm{m}\end{array}$ & $\begin{array}{l}\mathrm{R}^{2} \\
\mathrm{R}^{2}\end{array}$ & $\begin{array}{l}\text { Cross } \\
R^{2}\end{array}$ \\
\hline $\mathrm{Cu}$ & Exponential & 6500 & 425 & 0,0038 & 0,00541 & 70,24 & 3630 & 0,758 & 0,204 \\
$\mathrm{Mn}$ & Exponential & 7200 & 720 & 1,861 & 3,725 & 49,96 & 20370 & 0,847 & 0,115 \\
$\mathrm{Fe}$ & Exponential & 4000 & 320 & 0,0074 & 0,1248 & 5,93 & 1191 & 0,722 & 0,206 \\
$\mathrm{Zn}$ & Exponential & 5500 & 410 & 0,0895 & 0,286 & 31,29 & 5580 & 0,922 & 0,260 \\
$\mathrm{PH}$ & Exponential & 5200 & 330 & 0,0038 & 0,033 & 11,52 & 1980 & 0,762 & 0,068 \\
\hline
\end{tabular}

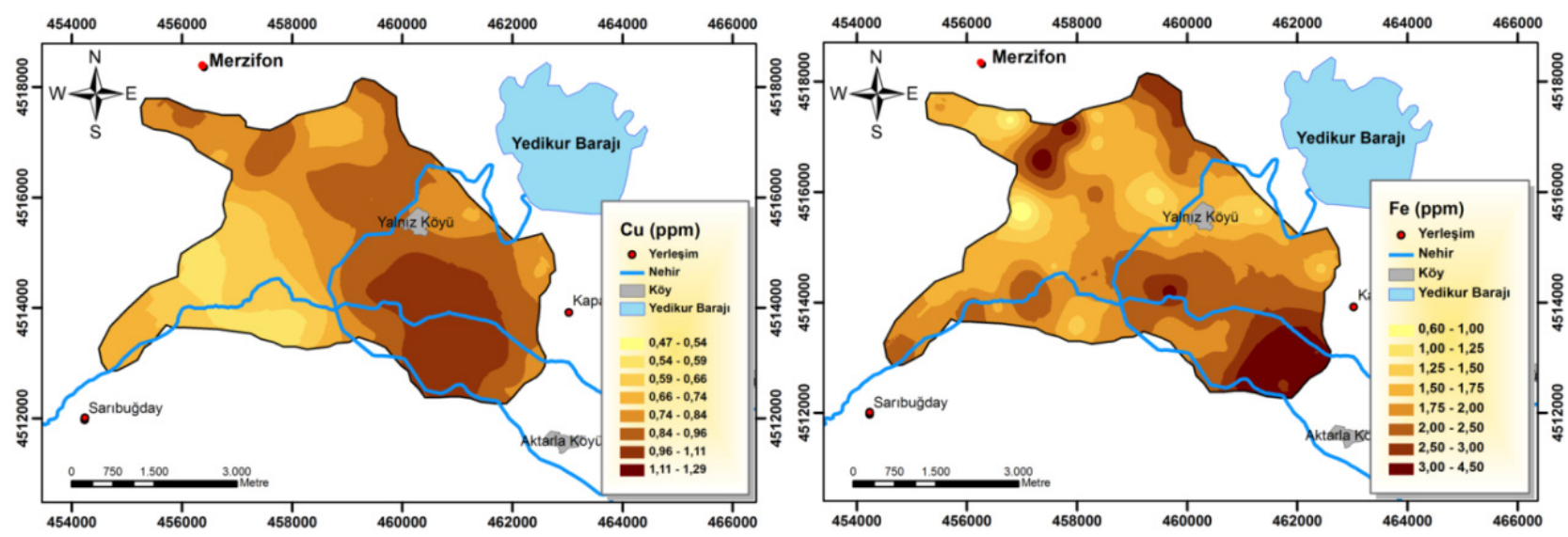

Șekil 2. Merzifon Ovasında Cu ve Fe içeriğinin mesafeye bağlı değișimi

Figure 2. Spatial distribution maps of Cu and Fe for Merzifon Plain 
Merzifon Ovasının tamamı Cu açısından sorunsuzdur, bununla birlikte $\mathrm{Cu}$ içeriğinin en yüksek olduğu topraklar $\left(0,74-1,19 \mathrm{mg} \mathrm{kg}^{-1}\right.$ arası) çoğunlukla ovanın güney doğusunda yer alan Aktarla Köyü ile Yalnız Köyü arasında yer almaktadır. Bahsedilen bu alanlar çoğunlukla kil içeriğinin \%50'den fazla olduğu alanlar olarak göze çarpmaktadır.

Bakır konsantrasyonu ile Fe konsantrasyonunun arazideki minimum ve maksimum değerlerinin bulunduğu bölgeler birbirlerine büyük benzerlik göstermektedir. Demir açısından yetersiz $12,5 \mathrm{mg}$ $\mathrm{kg}^{-1}$ ) olan alanlar çoğunlukla Yalnız Köyü ve etrafından ovanın kuzey doğusuna doğru kıvrımlı bir hat șeklinde uzanmaktadır (Șekil 2).
Çalıșma alanının tamamında yeterli konsantrasyonda bulunan $\mathrm{Mn}$ içeriğinin en düșük olduğu örnekleme noktaları arazinin kuzey batı kısmında yer almaktadır. Bunun tam tersi istikamette yani ovanın güney-doğu kısmında ise Mn konsantrasyonunun 6,0-8,0 $\mathrm{mg} \mathrm{kg}^{-1}$ arasında değiștiği görülmektedir (Șekil 3).

Merzifon Ovasında Zn' nun (Șekil 3) ve $\mathrm{pH}^{\prime}$ nın (Șekil 4) değișimleri incelendiğinde, pH'nın düșük olduğu ovanın Güney Batı ucunda örneklenen arazilerde Zn' nun yeterli konsantrasyonda olduğu, bunun haricindeki hemen hemen tüm arazilerde ise noksanlık sınır değeri olan $0,5 \mathrm{mg} \mathrm{kg}^{-1}$ ın altında olduğu görülmektedir.
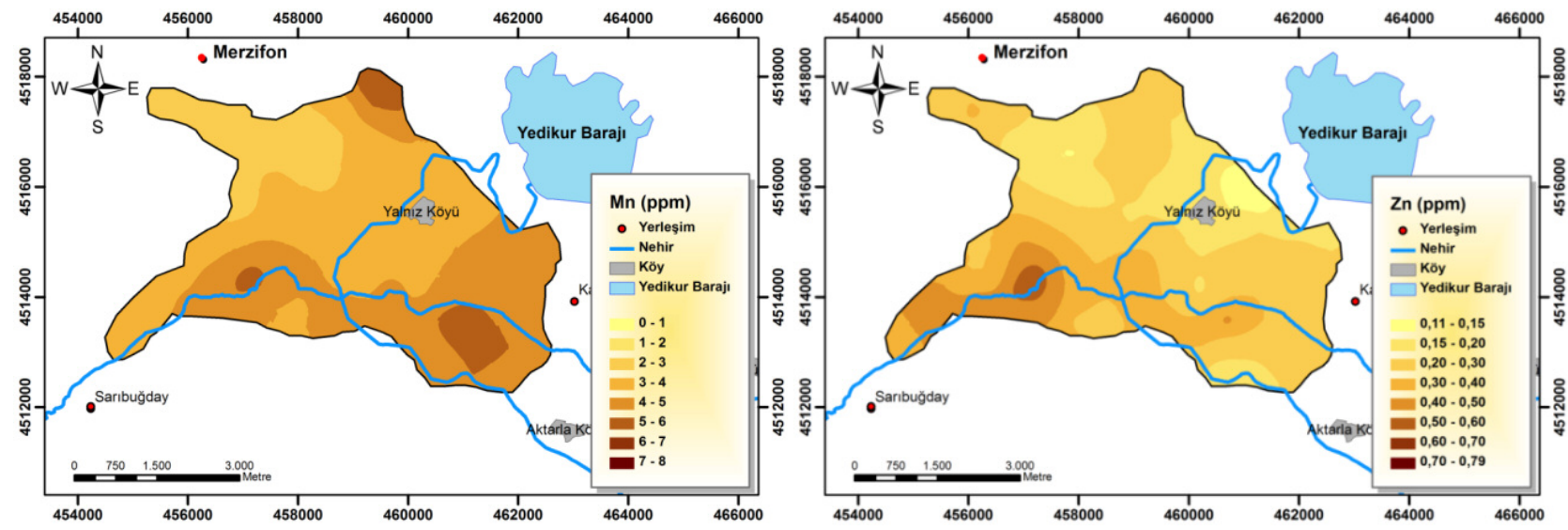

Șekil 3. Merzifon Ovasında Mn ve Zn içeriklerinin mesafeye bağlı değișimi

Figure 3. Spatial distribution maps of Mn and Zn for Merzifon Plain

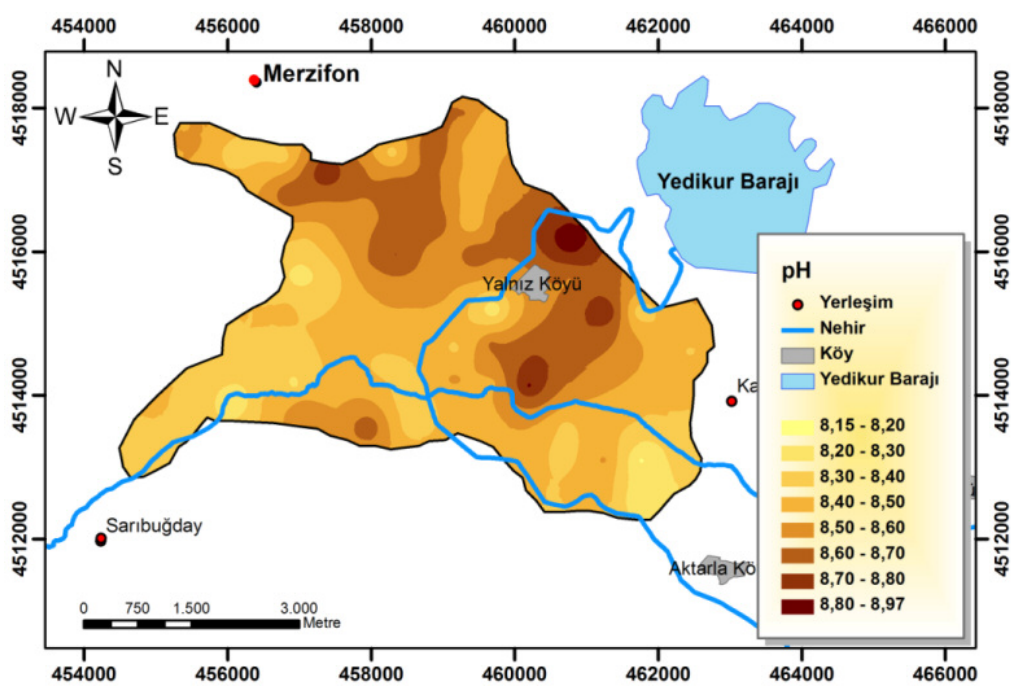

Șekil 4. Merzifon Ovasında pH değerlerinin mesafeye bağlı değișimi

Figure 4. Spatial distribution maps of $\mathrm{pH}$ values for Merzifon Plain 


\section{Suluova Ovası Topraklarının Mesafeye Bağlı Değișimleri}

Suluova Ovası topraklarının Merzifon topraklarına nazaran mesafeye bağımlılıklarının daha yüksek olduğu görülmektedir. Suluova Ovasında Mn, Fe ve Zn yüksek düzeyde uzaysal bağımlı iken, Cu' ın orta düzeyde bağımlı olduğu belirlenmiștir. Mikro

elementler içerisinde ise range değeri en düșük olanlar 1110 m ile Mn ve 1120 m ile Zn olarak belirlenmiștir. Mesafeye bağımlı̆̆ğ orta düzeyde olan $\mathrm{Cu}$ ise, mikro elementler içerisinde range değeri en yüksek özellik olarak tespit edilmiștir (Çizelge 5).

Çizelge 5. Suluova Ovası toprakları semivaryogram model parametreleri

Table 5. Semivariogram model parameters of Suluova Plain soils

\begin{tabular}{llllllllll}
\hline Model & $\begin{array}{l}\text { Aktif } \\
\text { Lag } \\
\text { Mesafesi }\end{array}$ & $\begin{array}{l}\text { Uniform } \\
\text { Aralık }\end{array}$ & $\begin{array}{l}\text { Nugget } \\
\text { Varyansı } \\
\text { Co }\end{array}$ & $\begin{array}{l}\text { Sill } \\
\text { Co+C }\end{array}$ & $\begin{array}{l}\text { Uzaysal } \\
\text { Bağımlılık } \\
\%\end{array}$ & $\begin{array}{l}\text { Range } \\
\text { (A) m }\end{array}$ & $\begin{array}{l}R^{2} \\
R^{2}\end{array}$ & $\begin{array}{l}\text { Cross } \\
R^{2}\end{array}$ \\
\hline Cu & Spherical & 7000 & 400 & 0,01709 & 0,04658 & 36,69 & 3080 & 0,847 & 0,344 \\
Mn & Exponential & 7000 & 425 & 0,258 & 1,955 & 13,20 & 1110 & 0,733 & 0,042 \\
Fe & Exponential & 7000 & 450 & 0,0115 & 0,10 & 11,50 & 1440 & 0,711 & 0,026 \\
Zn & Spherical & 5000 & 350 & 0,0001 & 0,3122 & 0,03 & 1120 & 0,769 & 0,018 \\
pH & Spherical & 7000 & 500 & 0,0259 & 0,0767 & 33,77 & 2790 & 0,954 & 0,242 \\
\hline
\end{tabular}
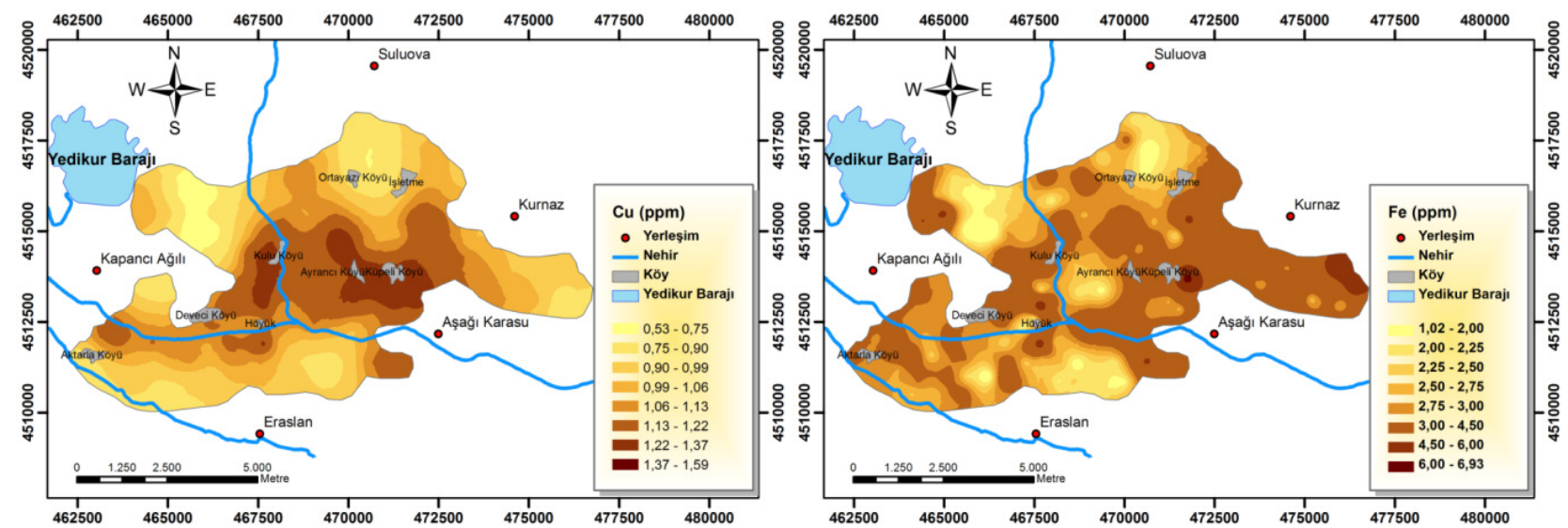

Șekil 5. Suluova Ovasında Cu ve Fe içeriklerinin mesafeye bağlı değișimi

Figure 5. Spatial distribution maps of Cu and Fe for Suluova Plain
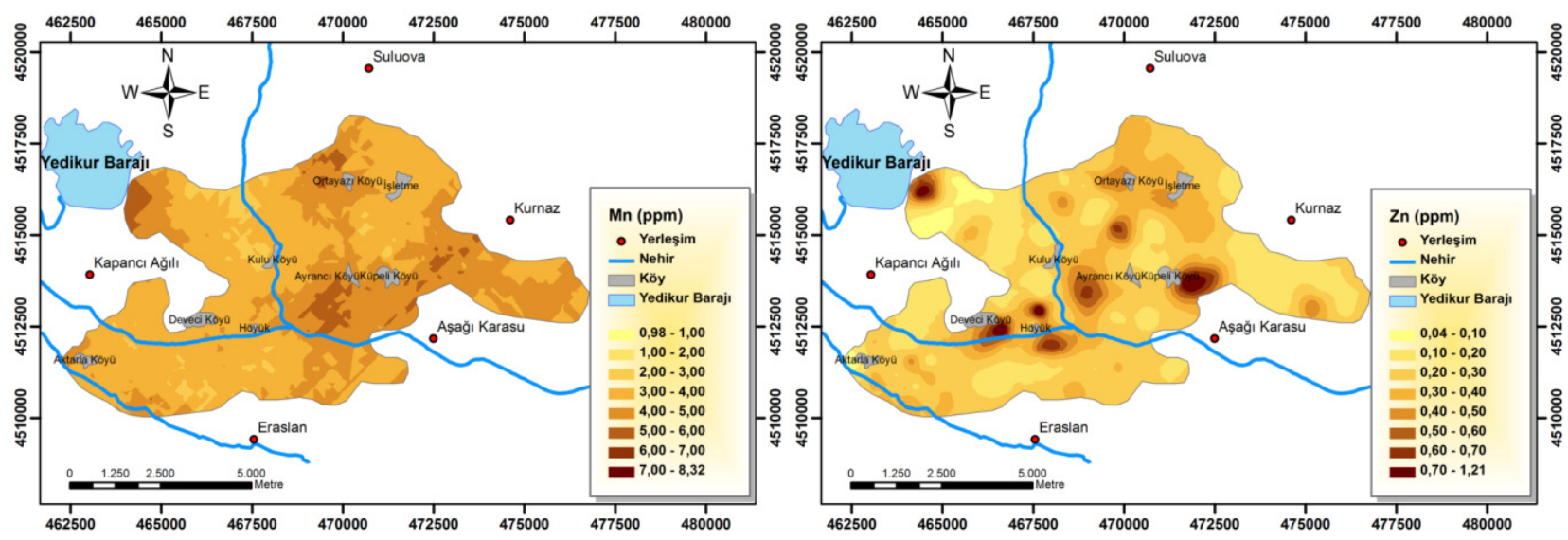

Șekil 6. Suluova Ovasında Mn ve Zn içeriklerinin mesafeye bağlı değișimi

Figure 6. Spatial distribution maps of Mn and Zn for Suluova Plain 


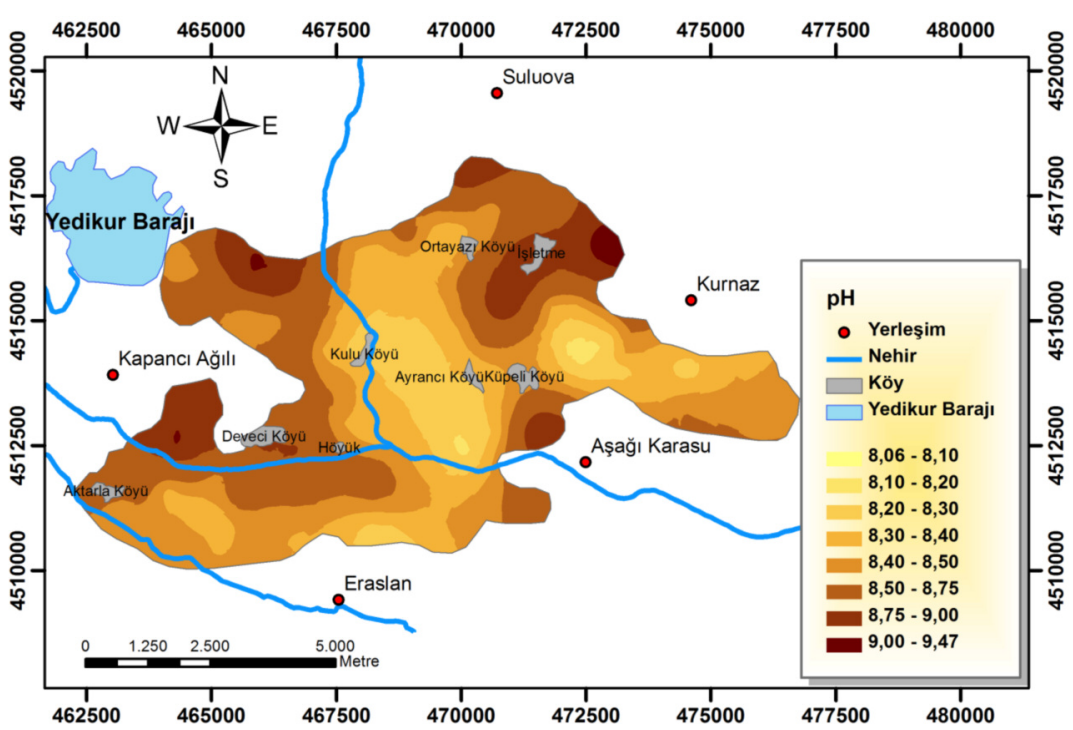

Șekil 7. Suluova'da pH değerlerinin mesafeye bağlı değișimi

Figure 7. Spatial distribution maps of $\mathrm{pH}$ values for Suluova Plain

Suluova Ovasında da Merzifon ovasında olduğu gibi kil içeriği ve Fe konsantrasyonunun yüksek olduğu bölgelerde, DTPA ile ekstrakte edilebilen Cu konsantrasyonunun yüksek olduğu görülmektedir (Șekil 5).

Suluova Ovasında örneklenen 143 noktanın tamamında topraklar bitki gelișimi açısından yeterli $\mathrm{Mn}$ içermektedirler. Bununla beraber $\mathrm{Mn}^{\prime}$ nın mesafeye bağı değișkenliğinin ifade edildiği haritada da görüldüğü gibi, kuzeyden gelen dere yatağı boyunca daha düșük konsantrasyonlarda olan Mn, Ortayazı ve Ayrancı Köyleri hattında daha yüksek konsantrasyonlardadır (Șekil 6).

Calıșma alanı topraklarının Zn konsantrasyonuna ait harita incelendiğinde, ovanın oldukça büyük bir kısmında Zn noksanlığının olduğu ve bitkisel üretimde verim artıșı sağlamak için mutlaka Zn içeren gübrelerin kullanılması gerektiği görülmektedir (Șekil 6). Her ne kadar korelasyon analizinde önemli bir ilișki görülmemiș olsa da, Suluova Ovasının pH haritasında pH'nın düșük olduğu hatların mikro besin elementi konsantrasyonlarının nispeten daha yüksek olduğu görülmektedir (Șekil 7).

\section{SONUCLAR}

Orta Karadeniz Bölgesinde geçit iklim kușağında yer alan Suluova Ovası (6019,3 ha) ve Merzifon $(2644,7$ ha) ovalarında yer alan kireç içeriği yüksek topraklarda mikro elementlerin yarayıșllık durumlarının tespiti, diğer toprak özellikleri ile ilișkileri ve mesafeye bağlı değișimlerinin modellenerek haritalanması bitkisel üretimin planlanması ve girdilerin doğru kullanımı açısından oldukça önemlidir. Çalıșma alanında 220 noktada $500 m$ 500m genișliğindeki gridlerin köșe noktalarından alınan temsili yüzey topraklarının (0$30 \mathrm{~cm})$ analiz sonuçları, özellikle $\mathrm{Zn}$ ve $\mathrm{Fe}$ noksanlığının bitkisel üretimde hedeflenen, arzu edilen ve beklentileri karșilayabilecek bir bitkisel üretimin önünde önemli sorunlar olarak ortaya çımaktadır. Zira her iki besin elementinin konsantrasyonları hem Suluova Ovası hem de Merzifon ovasında örneklenen arazilerin büyük çoğunluğunda noksanlık için belirlenen sınırların altındadır. Eksiklik görülen alanlarda geleneksel bitkisel üretimde çokça yer verilmeyen Zn ve Fe gibi mikro elementleri barındıran gübrelere yer vermek, bu sorunun çözümüne yardımcı olabilecektir. Bununla birlikte, çalıșma alanının tamamında toprakların yarayıșlı $\mathrm{Cu}$ ve $\mathrm{Mn}$ açısından yeterli olduğu ve bitkisel üretim için bu iki mikro besin elementi ile ilgili bir gübrelemenin gereksiz olduğu tespit edilmiștir. Elbette, $\mathrm{pH}$ ve kirec içeriğinin yüksek olmasının bu iki besin elementinin yarayıșlılıklarını etkileyebileceği ve gelecekte bitkisel üretimi tehdit edebilecek iki önemli etken olabileceğinin unutulmaması gerekmektedir.

Bu çalıșmada ortaya konulan mesafeye bağlı değișkenlik haritaları, tarımsal üretim ile ilgili kurum ve kurulușların bitkisel üretimde verimlilik ve bitkisel üretim deseni olușturulması gibi çalıșmalarına altı olușturabilecek niteliktedir. Coğrafi koordinatları kayıtlı olan örnekleme noktalarının varlığı, alanda 
belirlenen özelliklerin zaman içerisindeki değișimlerinin izlenmesine olanak vereceğinden, toprak kalitesi ile ilgili gelecekte yapılan çalıșmalar için güvenilir bir referans olacaktır.

\section{Teșekkür}

Bu çalıșma Elif Günal tarafından GaziOsmanpașa Üniversitesi Fen Bilimleri Enstitüsü Toprak Bilimi ve Bitki Besleme Ana Bilim Dalında yapılan yüksek lisans tezini kapsamaktadır.

\section{KAYNAKLAR}

Allison LE, Moodie CD (1965). Carbonate. In: C.A. Black et al (ed.) Methods of Soil Analysis, Part 2. Agronomy (9):13791400. Am. Soc. Of Agron., Inc., Mad., Wisc, U.S.A.

Alloway BJ (2008). Micronutrient deficiencies in global crop production. Dordrecht, The Netherlands: Springer. 353 p.

Behera SK, Singh MV, Singh KN, Todwal S (2011). Distribution variability of total and extractable zinc in cultivated acid soils of India and their relationship with some selected soil properties. Geoderma (162): 242-250.

Camberdella CA, Moorman TB, Novak JM, Parkin TB, Karlen DL, Turco RF, Konopka AE (1994). Field scale variability soil properties in Central lowa soils. Soil Sci. Soc. Am. J. (58):15011511 .

Çoban A (2003). Tarıma dayalı sanayinin beșerî ve ekonomik bakımdan hızı değișim sürecine etkileri üzerine bir örnek: SULUOVA. GÜ, Gazi Eğitim Fakültesi Dergisi, 23 (3):7187.

Dudley LM, Mclean JE, Furst TH, Jurinak JJ (1991). Sorption of cadmium and copper from an acid mine waste extract by two calcareous soils: Column studies. Soil Sci., 151(2): 121135.

Erdem H, Budak M, Acir N, Gokmen F, (2012). Micronutrient variability in a lacustrine environment of calcic haplosalids. Fresenius Environmental Bulletin, 21 (3), 553-562.

Esri (2006). Environmental System Research Institute. Redland CA,USA.

FAO. (1990). Micronutrient, Assessment at the Country Level: An International Study. FAO Soil Bulletin by Sillanpaa. Rome.

Follet $\mathrm{RH}(1969)$. Zn, Fe, $\mathrm{Mn}$ and $\mathrm{Cu}$ in Colorado Soils. PhD. Dissertation. Colo. State Univ.

Foroughifar $\mathrm{H}$, Jafarzadeh AA, Torabi $H$, Pakpour A, Miransari M (2013). Using geostatistics and geographic information system techniques to characterize spatial variability of soil properties, including micronutrients. Communications in Soil Science and Plant Analysis, 44(8):1273-1281.

Gamma Design Software (2004). GS+; Geostatistics for the Environmental Sciences. Plainwell, Michigan, United States, Gamma Design Software.

Gee GW, Bauder JW (1 986). Particle-size Analysis. P. 383 411. In: A.L.Page (ed.). Methods of soil analysis, Part 1, Physical and mineralogical methods. Second Edition, Agronomy Monograph 9, American Society of Agronomy, Madison, WI.
Ghasemi-Fasaei R, Maftoun M, Ronaghi A, Karimian N, Yasrebi J, Assad MT, Ippolito JA. (2006). Kinetics of copper desorption from highly calcareous soils. Communications in Soil Science and Plant Analysis 37:797-809.

Havlin JL, Beaton JD, Tisdale SL, Nelson WL, (1999). Soil fertility and fertilizers. An introduction to nutrient management, 6th ed. Prentice Hall, Upper Saddle River, NJ.

Heuvelink GBM, Webster R (2001). Modelling soil variation: Past, present and future. Geoderma (100):269-301.

Hodges SC (2010). Soil fertility basics. Soil Science Extension, North Carolina State Univ.

Hong E, Ketterings Q, McBride M. (2010). Manganese. Nutrient Management Spear Program Agronomy Fact Sheet Series. http://nmsp.cals.cornell.edu. Fact Sheet 49.

Lindsay WL, Norwell WA (1978). Development of DTPA Soil Test for zinc, iron, manganese and copper. Soil Sci. Soc. Am. J. 42(3):421-428.

McBratney AB, Odeh IOA, Bishop TFA, Dunbar MS, Shatar TM (2000). An overwiev of pedometric techniques for use in soil survey. Geoderma 97 (3-4): 293-327.

Nael M, Khademi H, Jalalian A, Schulin R. (2009). Effect of geo-pedological conditions on the distribution and chemical speciation of selected trace elements in forest soils of western Alborz, Iran. Geoderma 152: 157-170.

Najafi-Ghiri M, Ghasemi-Fasaei, R, Farrokhnejad E. (2013). Factors affecting micronutrient availability in calcareous soils of Southern Iran. Arid Land Research and Management, 27(3), 203-215.

Nelson DW, Sommer LE (1982). Total carbon, organic carbon, and organic matter. p. 539-579. In A.L. Page (ed.) Methods of Soil Analysis. 2nd Ed. ASA Monogr. 9(2). Amer. Soc. Agron. Madison, WI.

Pegoraro RF, Silva IR, Novais RF, Mendonça ES, Gebrim F, Moreira FF (2006). Fluxo difuso e biodisponibilidade de zinco, cobre, ferro e manganês no solo: influência da calagem, textura do solo e resíduos vegetais. Revista Brasileira de Ciência do Solo, 30:859-868.

Reyhanitabar A, Karimian N (2008). Kinetics of copper desorption of selected calcareous soils from Iran. Am Eur J Agric Environ Sci, 4(3):287-293.

Rhoades JD (1982). Cation exchange capacity. In: Page AL, Miller RH, Keeney DR (eds.) Methods of soil analysis. Part 2. Agron. Monogr. 9, Am. Soc. Agron., Madison, WI. P. 149-157.

Sharma BD, Kumar R, Singh B, Sethi M. (2009). Micronutrients distribution in salt-affected soils of the Punjab in relation to soil properties. Archives of Agronomy and Soil Science, 55(4), 367-377

Sharma BD, Arora H, Kumar R, Nayyar VK. (2004). Relationship between soil characteristics and total and DTPAextractable micronutrients in Inceptisols of Punjab. Communication in Soil Science and Plant Analysis 35: 799818.

Sharma BD, Jassal HS, Sawhney JS, Sidhu PS, (1999). Micronutrient distribution in different physiographic units of the Siwalik hills of the semiarid tract of Punjab, India. Arid Land Research and Management 13(2): 189-200. 
Tümsavaș Z, Çelik I. (2005). Bursa ili kireçsiz kahverengi topraklarının bazı özellikleri ve besin elementleri içerikleri. C.. Ü Z. F. Dergisi, 20(1): 69-83.

Ülgen N, Yurtsever N (1974). Türkiye Gübre ve Gübreleme Rehberi. Toprak ve Gübre Araștırma Enstitüsü Teknik Yayın No:28, Ankara.

Vieira SR, Nielsen DR., Biggar JW. (1981). Spatial variability of field-measured infiltration rate. Soil Sci. Soc. Am. J., 45: 10401048 .
Wenming D Zhijun G, Jinzhou D, Liying Z, Zuyi T, (2001). Sorption characteristics of Zn (III) by calcareous soil-radiotracer study. Applied Radiation and Isotopes 54, 371-375.

White JG, Zasoski RJ (1999). Mapping soil micronutrients. Field Crops Research, 60 (1):11-26.

Wu C, Luo Y, Zhang L, (2010). Variability of copper availability in paddy fields in relation to selected soil properties in southeast China. Geoderma 156: 200-206. 